\title{
The 100 most cited papers on thymic epithelial tumours: a bibliometric analysis
}

\author{
Guanghao Qiu, Fuqiang Wang, Hanlu Zhang, Yu Zheng, Zihao Wang, Yun Wang \\ Department of Thoracic Surgery, West China Hospital, Sichuan University, Chengdu, China \\ Contributions: (I) Conception and design: G Qiu; (II) Administrative support: Y Wang; (III) Provision of study materials or patients: G Qiu, F Wang; \\ (IV) Collection and assembly of data: H Zhang, Y Zheng; (V) Data analysis and interpretation: H Zhang, Y Zheng, Z Wang; (VI) Manuscript \\ writing: All authors; (VII) Final approval of manuscript: All authors. \\ Correspondence to: Yun Wang, MD, PhD. Department of Thoracic Surgery, West China Hospital, Sichuan University, No. 37, Guoxue Alley, Chengdu \\ 610041, China. Email: yunwwang@yeah.net.
}

\begin{abstract}
Bibliometric analysis can help us analyse the most influential papers, authors, research institutions in a discipline or topic and analyse the impact of these papers on a specific field. Our purpose is to identify the 100 most cited papers about thymic epithelial tumours (TETs) and analyse their key characteristics. We use certain search terms in the Web of Science database to identify the 100 most cited papers, and analysed the first author, country of the first author, institution, journal, type of paper, number of citations, and citation rate. The search returned 26,497 results. The top 100 papers received 17,674 citations. The most cited paper was by Masaoka et al. ( $\mathrm{n}=1,190$ citations), in which, clinical staging criteria are proposed for thymoma with special emphasis on the therapy and prognosis. The paper with the highest citation rate was also by Masaoka et al. (citations rate $=30.51$ ). Osaka University published the most papers $(\mathrm{n}=6)$ and accrued the highest number of citations ( $\mathrm{n}=2,122$ citations). The United States was the country with the most published papers $(n=45)$ and the highest number of citations ( $n=7,991$ citations). Cancer is the journal with the most published papers $(n=19)$ and the highest number of citations $(n=5,017$ citations). Through the analysis of the most influential papers, this study provides a reference for researchers trying to understand TETs, thus providing guidance for future research.
\end{abstract}

Keywords: Thymic epithelial tumours (TETs); thymoma; thymic tumour; bibliometric analysis; citations

Submitted Aug 21, 2020. Accepted for publication Oct 25, 2020.

doi: $10.21037 /$ jtd-20-2706

View this article at: http://dx.doi.org/10.21037/jtd-20-2706

\section{Introduction}

Thymic epithelial tumours (TETs), are a group of epithelial tumours originated from thymic epithelium, including thymoma, thymic carcinoma, and thymic neuroendocrine tumours, most of which mainly located in the anterior mediastinum of adults. TETs are a relatively rare type of malignant mediastinal tumours with an incidence of $<1 \%$ of all adult cancers $(1,2)$. Also, TETs are typically indolentgrowing tumours because the survival of the patients with TETs is longer even after disease progression. Therefore, some scholars suggested a longer follow-up (10 years) for TETs, focusing on the patient's overall survival (OS) and recurrence (3).
Bibliometric citation analysis is a direct and standardized method used to assess the strengths, trends and gaps in a certain field. It uses the number of citations received in scientific papers to develop citation rankings to assess the impact and quality of these papers (4).

TETs are the most common type of anterior mediastinal tumours. So far, however, there has been no bibliometric analysis of the literature on TETs. The purpose of this citation analysis is to understand the most important research into TETs by studying the year of publication, first author, country of the first author, institution, journals, type of paper, number of citations, and citation rate. 


\section{Methods}

\section{Search methodology}

We used the Web of Science citation indexing database for research. The search strategy was to identify papers that contained specific search terms/keywords in their title, abstract or topic. After an independent trial search by two authors (GQ, FW), the following keywords were used in the final search: "thymic epithelial tumours" OR thymoma OR "thymic carcinoma" OR "thymic tumours" OR "thymic neoplasms" OR "thymic cancer" OR thymectomy OR thymomas. The search results were set to come from all databases within the Web of Science. Only papers written in English were selected. The final search date was $10 \mathrm{July}$ 2020.

\section{Paper selection}

The search results were sorted in descending order of "times cited", and then the two authors (GQ, FW) reviewed the included papers in order of total number of citations. Inclusion criteria are: (I) papers related to TETs; (II) papers written in English. The exclusion criteria are: (I) papers not related to the subject; (II) papers written in languages other than English; (III) papers focused on non-TETs topics, such as papers related to thymic diseases. The two researchers independently analysed the included papers and reviewed the full text of the included papers if necessary. When there were conflicts between the two researchers, the author (YW) would reconcile the difference. After the final 100 papers were determined, all included full texts were reviewed and the required data extracted.

\section{Data extraction}

We analysed the 100 most cited papers by the year of publication, first author, country of the first author, institution, journals, type of paper, number of citations, and citation rate; because older papers tend to accumulate more citations over time, thus we controlled for historical publication bias by calculating citation rate. Powell et al. proposed that the method of calculation of citation rate should be such that we divide the total number of citations of a paper by the number of years since the paper was published (citation). For papers with the same number of citations, we ranked them according to citation rate. Papers with higher citation rate were ranked higher.

\section{Results}

We retrieved 26,497 papers from Web of Science. Table 1 lists the 100 most cited papers. These 100 papers received a total of 17,674 citations, the number of citations ranged from 101 for Evoli et al. (Thymoma in patients with MG: characteristics and long-term outcome) to 1,190 for Masaoka et al. (Follow-up study of thymomas with special reference to their clinical stages). The earliest published paper of the 100 most cited papers was that by Gafni et al. (Idiopathic acquired agammaglobulinemia associated with thymoma. Report of two cases and review of the literature) which was published in 1960.

This type of bibliometric analysis has certain limitations: papers published earlier may accumulate more citations, thereby reducing the number of newly published papers among the 100 most cited papers. To control this, we divided the number of citations by the number of years since publication to get the citation rate. Table 2 lists the top 10 papers with the highest citation rate. The citation rate for the top 100 papers ranged from 1.87 for Gafni et al. (Idiopathic acquired agammaglobulinemia associated with thymoma. Report of two cases and review of the literature) to 30.51 for Masaoka et al. (Follow-up study of thymomas with special reference to their clinical stages).

The 100 most cited papers were published in 33 journals, with the number of papers per journal ranging from one to 19 (Table 3). Cancer published the most papers and had the highest number of citations ( $\mathrm{n}=19, \mathrm{n}=5,017$ citations). As shown in Table 4, the United States accounted for the most papers $(n=45)$ with a total of 7,991 citations, followed by Japan ( $\mathrm{n}=19, \mathrm{n}=4,200$ citations). Staff at Osaka University authored the most papers $(n=6)$ with a total of 2,111 citations (Table 5).

In Table 6, Detterbeck and Loehrer published the most papers $(n=4)$ with a total of 657 and 590 citations, respectively. However, Masaoka published two papers with the highest number of citations ( $\mathrm{n}=1,294$ citations).

According to the University of Oxford Centre for Evidence-Based Medicine guides and National Health and Medical Research Council of Australia, we analysed the top 100 papers by level of evidence and study type (Table 7$)(5,6)$. Five guidelines (level I/1, National Health and Medical Research Council of Australia/Centre for Evidence-Based Medicine), four RCTs (level II/2), and eight prospective papers (level III-2/3) reflected a high level of evidence. There were 50 retrospective papers (level III-3/4) in the list.

Fifteen authors contributed four or more papers to the 
Table 1 The top 100 cited papers on TETs

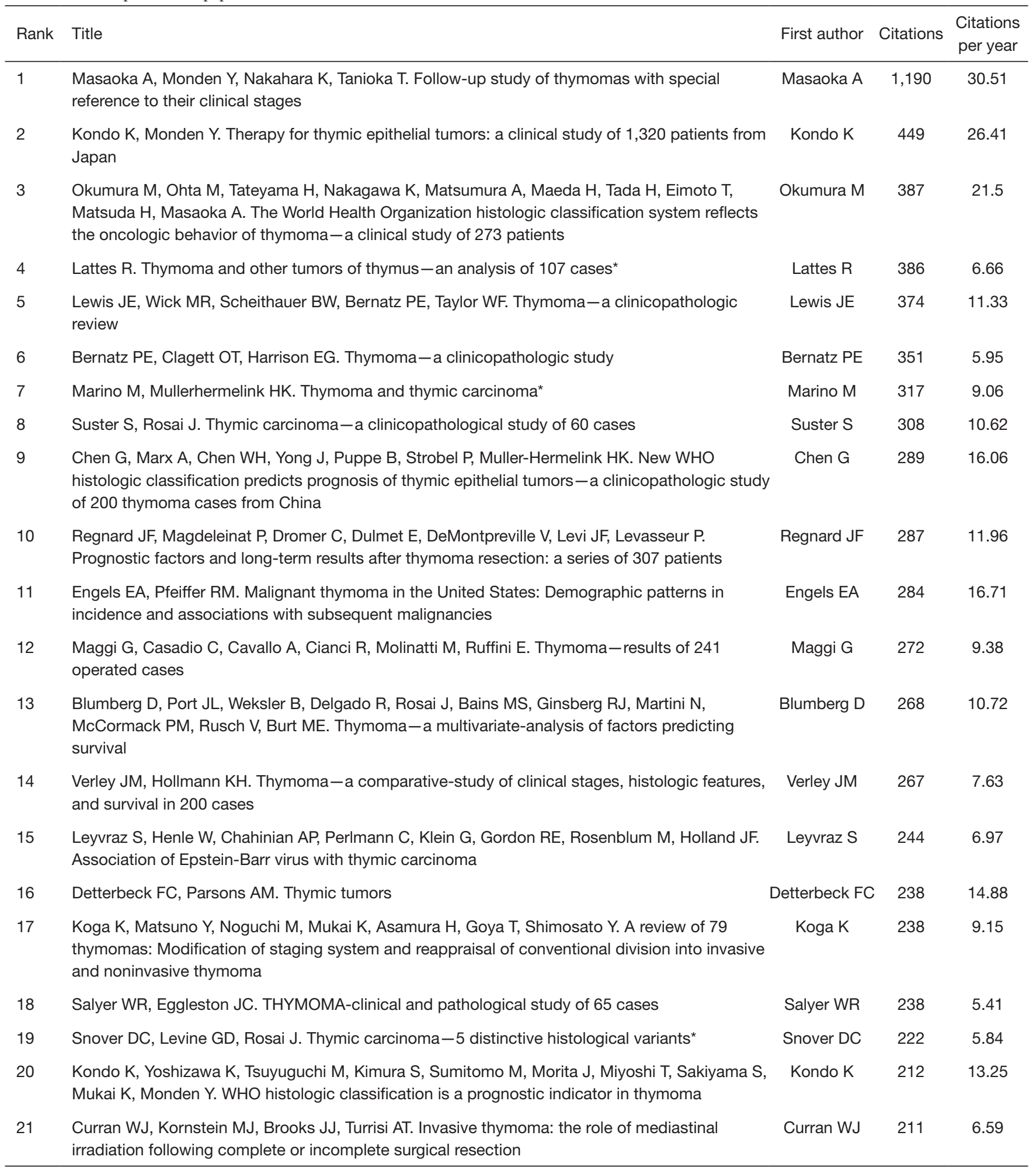

Table 1 (continued) 
Table 1 (continued)

\begin{tabular}{|c|c|c|c|c|}
\hline Rank & Title & First author & Citations & $\begin{array}{l}\text { Citations } \\
\text { per year }\end{array}$ \\
\hline 22 & $\begin{array}{l}\text { Strobel P, Bauer A, Puppe B, Kraushaar T, Krein A, Toyka K, Gold R, Semik M, Kiefer R, Nix W, } \\
\text { Schalke B, Muller-Hermelink HK, Marx A. Tumor recurrence and survival in patients treated for } \\
\text { thymomas and thymic squamous cell carcinomas: a retrospective analysis }\end{array}$ & Strobel P & 210 & 13.13 \\
\hline 23 & Engels EA. Epidemiology of thymoma and associated malignancies & Engels EA & 209 & 20.9 \\
\hline 25 & Eng TY, Fuller CD, Jagirdar J, Bains Y, Thomas CR. Thymoma: state of the art & Thomas CR & 192 & 9.14 \\
\hline 26 & $\begin{array}{l}\text { Kim ES, Putnam JB, Komaki R, Walsh GL, Ro JY, Shin HJ, Truong M, Moon H, Swisher SG, } \\
\text { Fossella FV, Khuri FR, Hong WK, Shin DM. Phase II study of a multidisciplinary approach with } \\
\text { induction chemotherapy, followed by surgical resection, radiation therapy, and consolidation } \\
\text { chemotherapy for unresectable malignant thymomas: final report }\end{array}$ & Kim ES & 188 & 11.75 \\
\hline 28 & $\begin{array}{l}\text { Abraham KM, Levin SD, Marth JD, Forbush KA, Perlmutter RM. Thymic tumorigenesis induced } \\
\text { by overexpression of p56lck }\end{array}$ & Abraham KM & 181 & 6.24 \\
\hline 29 & $\begin{array}{l}\text { Quintanillamartinez L, Wilkins EW, Choi N, Efird J, Hug E, Harris NL. Thymoma-histologic } \\
\text { subclassification is an independent prognostic factor }\end{array}$ & $\begin{array}{l}\text { Quintanilla- } \\
\text { martinez L }\end{array}$ & 175 & 6.73 \\
\hline 30 & $\begin{array}{l}\text { Nakahara K, Ohno K, Hashimoto J, Maeda H, Miyoshi S, Sakurai M, Monden Y, Kawashima Y. } \\
\text { Thymoma: results with complete resection and adjuvant postoperative irradiation in } 141 \\
\text { consecutive patients }\end{array}$ & Nakahara K & 175 & 5.47 \\
\hline 31 & $\begin{array}{l}\text { Oberg K, Hellman P, Ferolla P, Papotti M, Grp EGW. Neuroendocrine bronchial and thymic } \\
\text { tumors: ESMO clinical practice guidelines for diagnosis, treatment and follow-up }\end{array}$ & Oberg $\mathrm{K}$ & 168 & 21 \\
\hline 34 & $\begin{array}{l}\text { Fornasiero A, Daniele O, Ghiotto C, Piazza M, Fioredonati L, Calabro F, Rea F, Fiorentino MV. } \\
\text { Chemotherapy for invasive thymoma }\end{array}$ & Fornasiero A & 159 & 5.48 \\
\hline 35 & $\begin{array}{l}\text { Bergh NP, Gatzinsky P, Larsson S, Lundin P, Ridell B. Tumors of the thymus and thymic region: I. } \\
\text { clinicopathological studies on thymomas }\end{array}$ & Bergh NP & 158 & 3.76 \\
\hline 36 & $\begin{array}{l}\text { Wright CD, Wain JC, Wong DR, Donahue DM, Gaissert HA, Grillo HC, Mathisen DJ. Predictors of } \\
\text { recurrence in thymic tumors: Importance of invasion, World Health Organization histology, and } \\
\text { size }\end{array}$ & f Wright CD & 157 & 10.47 \\
\hline 37 & $\begin{array}{l}\text { Kelleher P, Misbah SA. What is Good's syndrome? Immunological abnormalities in patients with } \\
\text { thymoma }\end{array}$ & Kelleher P & 157 & 9.24 \\
\hline 38 & Wilkins EW, Edmunds LH, Castleman B. Cases of thymoma at massachusetts general hospital & Wilkins EW & 154 & 2.85 \\
\hline 39 & $\begin{array}{l}\text { Detterbeck FC, Nicholson AG, Kondo K, Van Schil P, Moran C. The Masaoka-Koga stage } \\
\text { classification for thymic malignancies: clarification and definition of terms }\end{array}$ & Detterbeck FC & 152 & 16.89 \\
\hline 40 & $\begin{array}{l}\text { Tarr PE, Sneller MC, Mechanic LJ, Economides A, Eger CM, Strober W, Cunningham-Rundles C, } \\
\text { Lucey DR. Infections in patients with immunodeficiency with thymoma (Good syndrome) }\end{array}$ & Tarr PE & 151 & 7.95 \\
\hline
\end{tabular}

Table 1 (continued) 
Table 1 (continued)

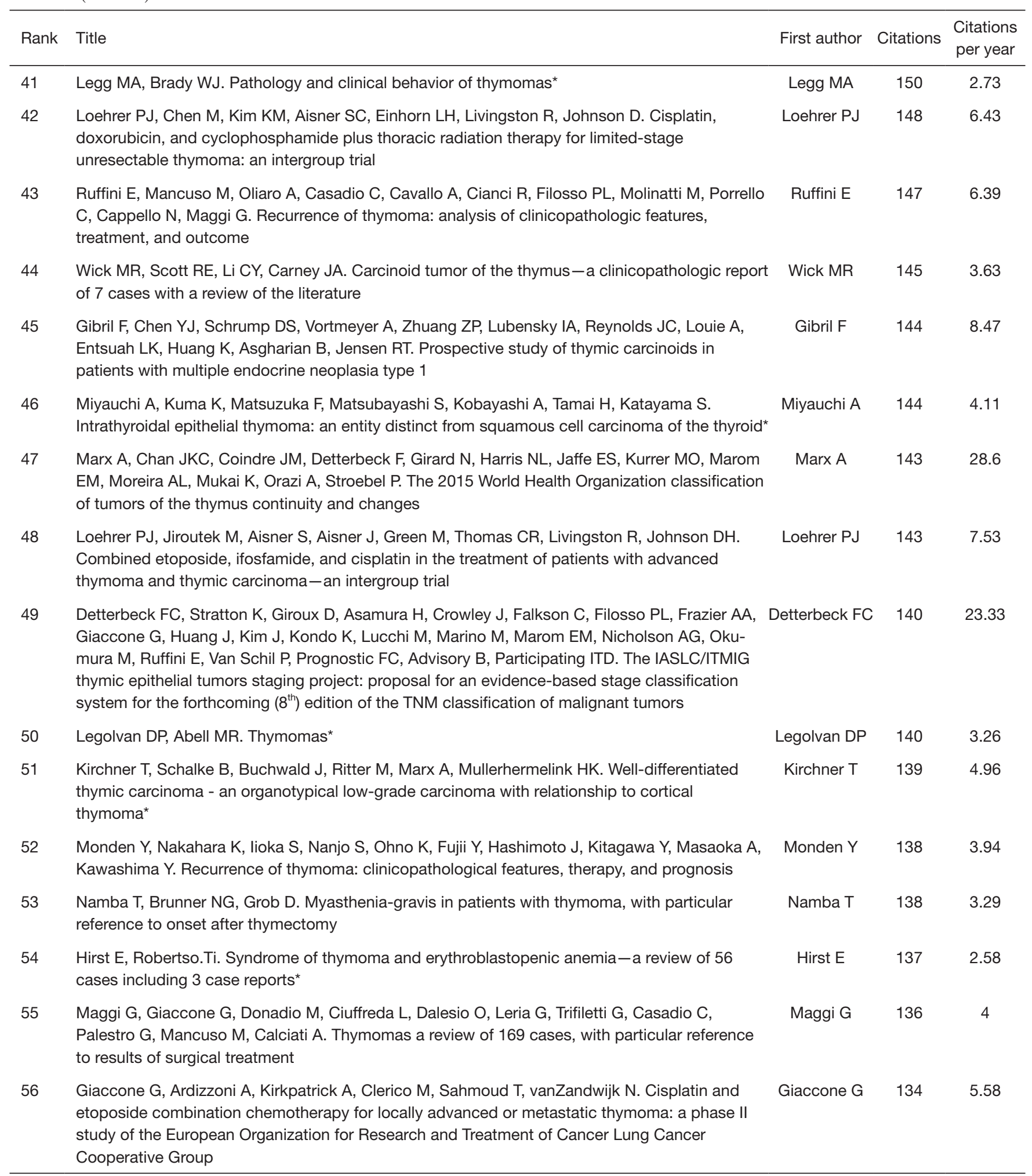

Table 1 (continued) 
Table 1 (continued)

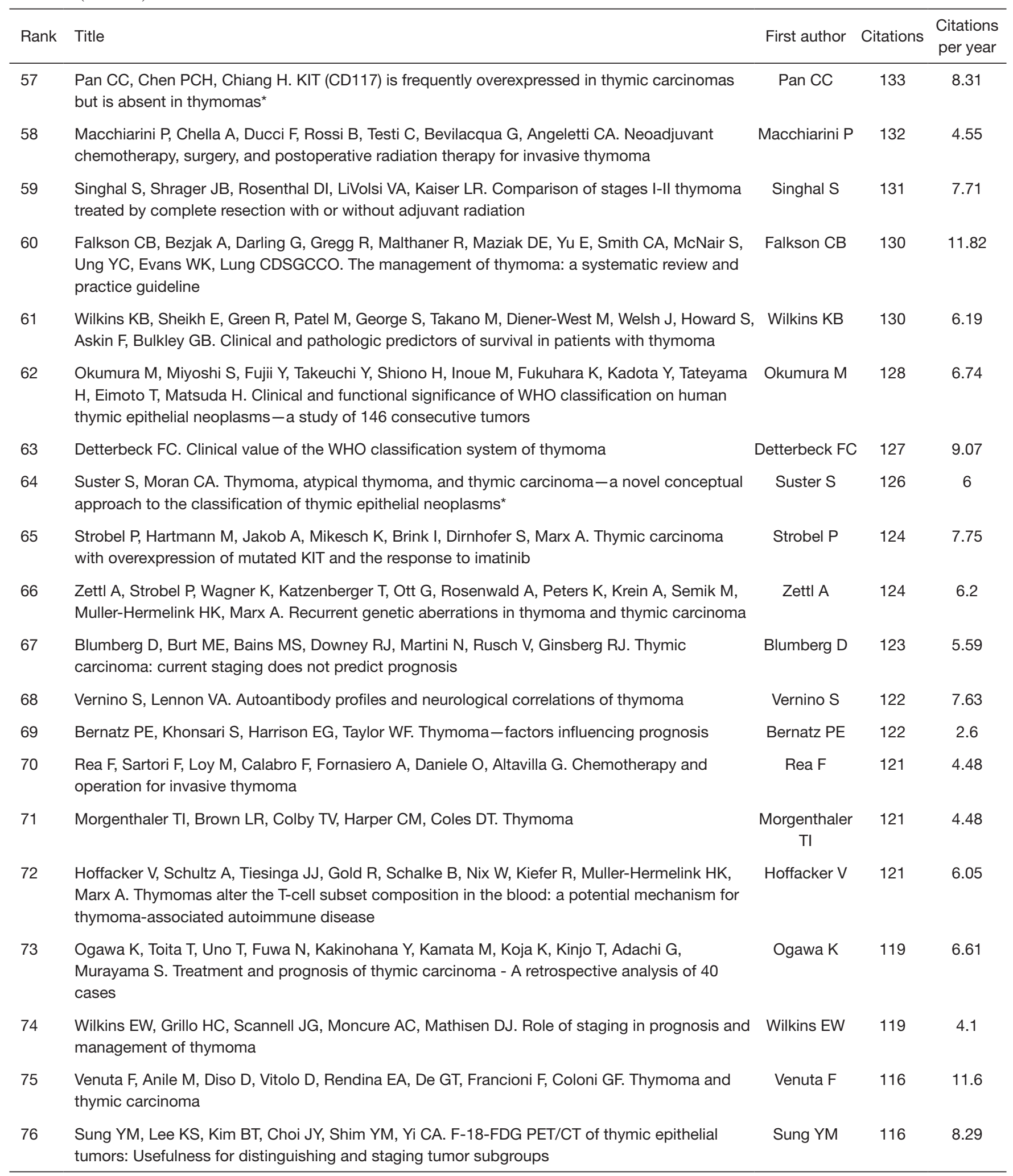

Table 1 (continued) 
Table 1 (continued)

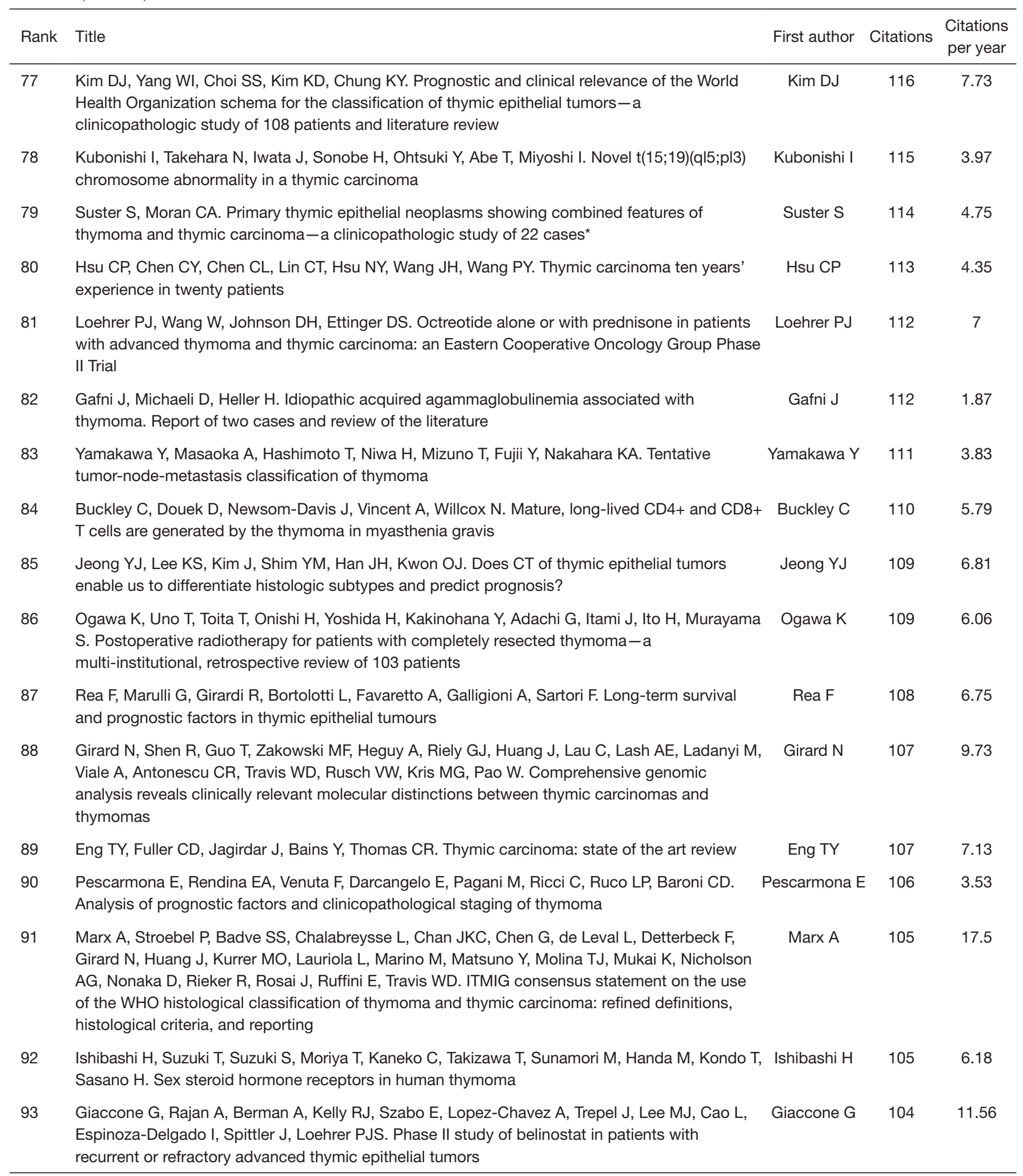

Table 1 (continued) 
Table 1 (continued)

\begin{tabular}{|c|c|c|c|c|}
\hline Rank & Title & First author & Citations & $\begin{array}{l}\text { Citations } \\
\text { per year }\end{array}$ \\
\hline 94 & Masaoka A. Staging system of thymoma & Masaoka A & 104 & 10.4 \\
\hline 95 & $\begin{array}{l}\text { Kaira K, Endo M, Abe M, Nakagawa K, Ohde Y, Okumura T, Takahashi T, Murakami H, Tsuya A, } \\
\text { Nakamura Y, Naito T, Hayashi I, Serizawa M, Koh Y, Hanaoka H, Tominaga H, Oriuchi N, Kondo H, } \\
\text { Nakajima T, Yamamoto N. Biologic correlation of 2-[F-18]-fluoro-2-deoxy-d-glucose uptake on } \\
\text { positron emission tomography in thymic epithelial tumors }\end{array}$ & Kaira K & 104 & 10.4 \\
\hline 96 & $\begin{array}{l}\text { Okumura M, Miyoshi S, Takeuchi Y, Yoon HE, Minami M, Takeda S, Fujii Y, Nakahara K, Matsuda } \\
\text { H. Results of surgical treatment of thymomas with special reference to the involved organs }\end{array}$ & Okumura M & 104 & 4.95 \\
\hline 97 & Gray GF. Thymoma-clinicopathologic study of 54 cases & Gray GF & 104 & 2.54 \\
\hline 98 & $\begin{array}{l}\text { Sadohara J, Fujimoto K, Mueller NL, Kato S, Takamori S, Ohkuma K, Terasaki H, Hayabuchi N. } \\
\text { Thymic epithelial tumors: Comparison of CT and MR imaging findings of low-risk thymomas, } \\
\text { high-risk thymomas, and thymic carcinomas }\end{array}$ & Sadohara J & 103 & 7.36 \\
\hline 100 & $\begin{array}{l}\text { Chalabreysse L, Roy P, Cordier JF, Loire R, Gamondes JP, Thivolet-Bejui F. Correlation of the } \\
\text { WHO schema for the classification of thymic epithelial neoplasms with prognosis - a } \\
\text { retrospective study of } 90 \text { tumors }\end{array}$ & $\begin{array}{l}\text { Chalabreysse } \\
\qquad \mathrm{L}\end{array}$ & 103 & 5.72 \\
\hline
\end{tabular}

*, article related to pathology. TET, thymic epithelial tumour.

Table 2 Top 10 papers with the highest citation rate

\begin{tabular}{|c|c|c|c|}
\hline Title & First author & Year & $\begin{array}{l}\text { Citations } \\
\text { per year }\end{array}$ \\
\hline Follow-up study of thymomas with special reference to their clinical stages & Masaoka A & 1981 & 30.51 \\
\hline Therapy for thymic epithelial tumors: a clinical study of 1,320 patients from Japan & Kondo K & 2003 & 26.41 \\
\hline $\begin{array}{l}\text { The World Health Organization histologic classification system reflects the oncologic behavior of } \\
\text { thymoma-a clinical study of } 273 \text { patients }\end{array}$ & Okumura M & 2002 & 21.5 \\
\hline $\begin{array}{l}\text { Neuroendocrine bronchial and thymic tumors: ESMO clinical practice guidelines for diagnosis, } \\
\text { treatment and follow-up }\end{array}$ & Oberg K & 2012 & 21 \\
\hline The Masaoka-Koga stage classification for thymic malignancies: clarification and definition of terms & Detterbeck FC & 2011 & 16.89 \\
\hline $\begin{array}{l}\text { Malignant thymoma in the United States: demographic patterns in incidence and associations with } \\
\text { subsequent malignancies }\end{array}$ & Engels EA & 2003 & 16.71 \\
\hline
\end{tabular}


Table 3 Journals that published the top 100 papers

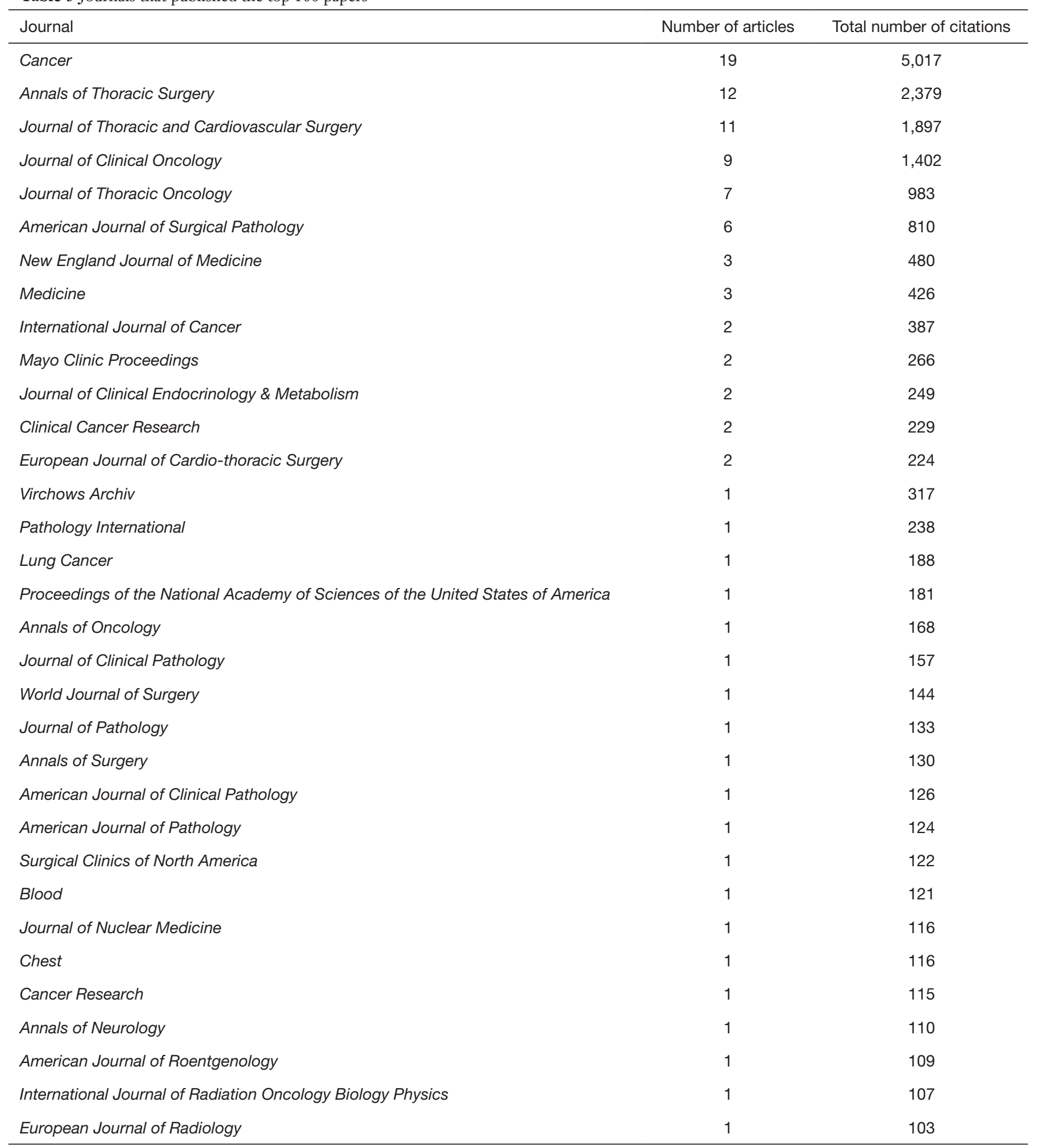


Table 4 Number of papers per country of origin in 100 most cited

\begin{tabular}{lcr}
\hline Country & Number of articles & Total number of citations \\
\hline United States & 45 & 7,991 \\
Japan & 19 & 4,200 \\
Italy & 11 & 1,775 \\
Germany & 8 & 1,069 \\
China & 3 & 535 \\
France & 3 & 657 \\
Sweden & 2 & 326 \\
Korea & 3 & 341 \\
United Kingdom & 2 & 267 \\
Australia & 2 & 137 \\
Europe & 1 & 134 \\
Canada & 1 & 130 \\
Israel & 1 & 112 \\
\hline
\end{tabular}

Table 5 Institutions with the highest number of papers in the top 100

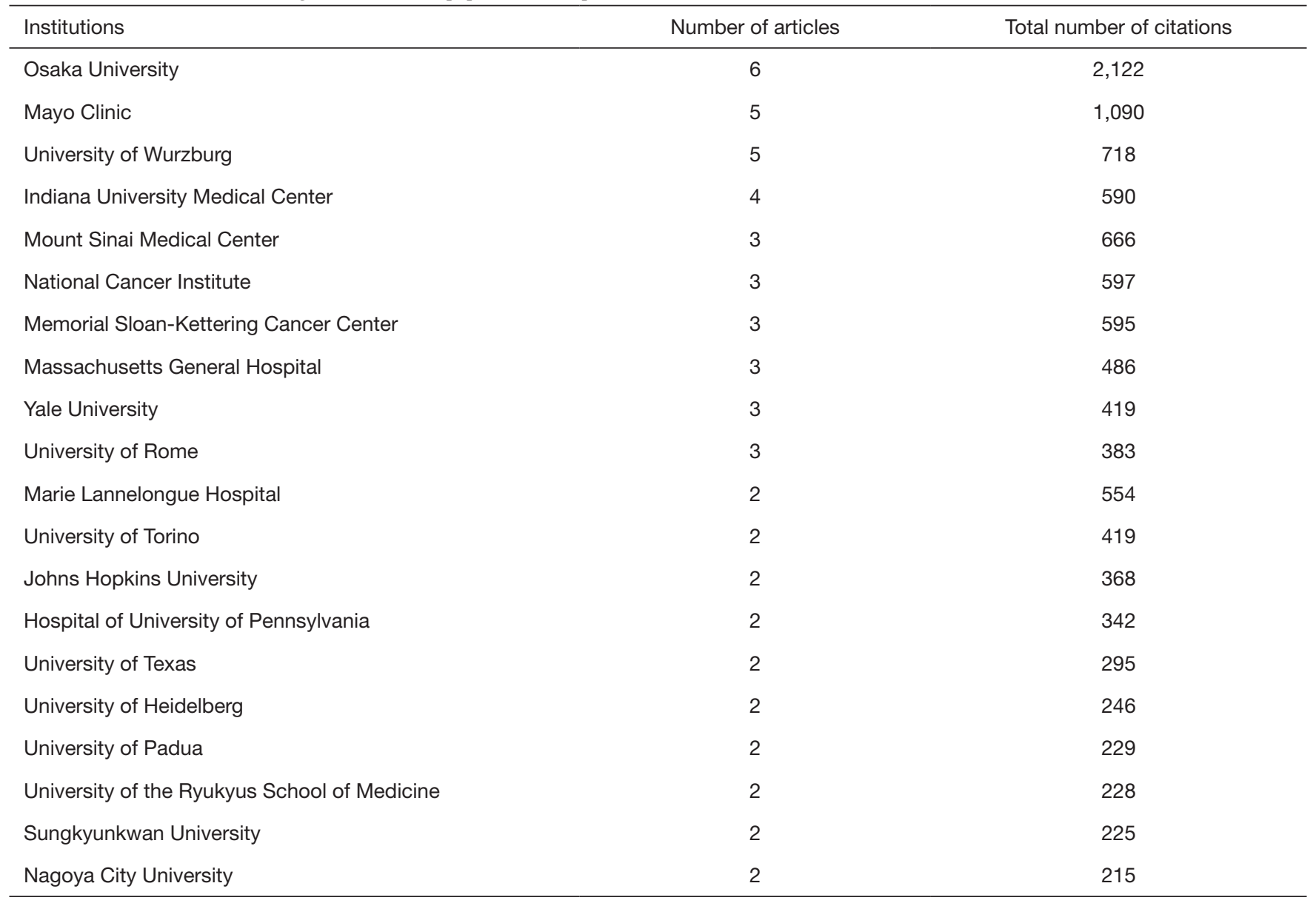


Table 6 Authors that contributed to more than one paper in the top 100 list

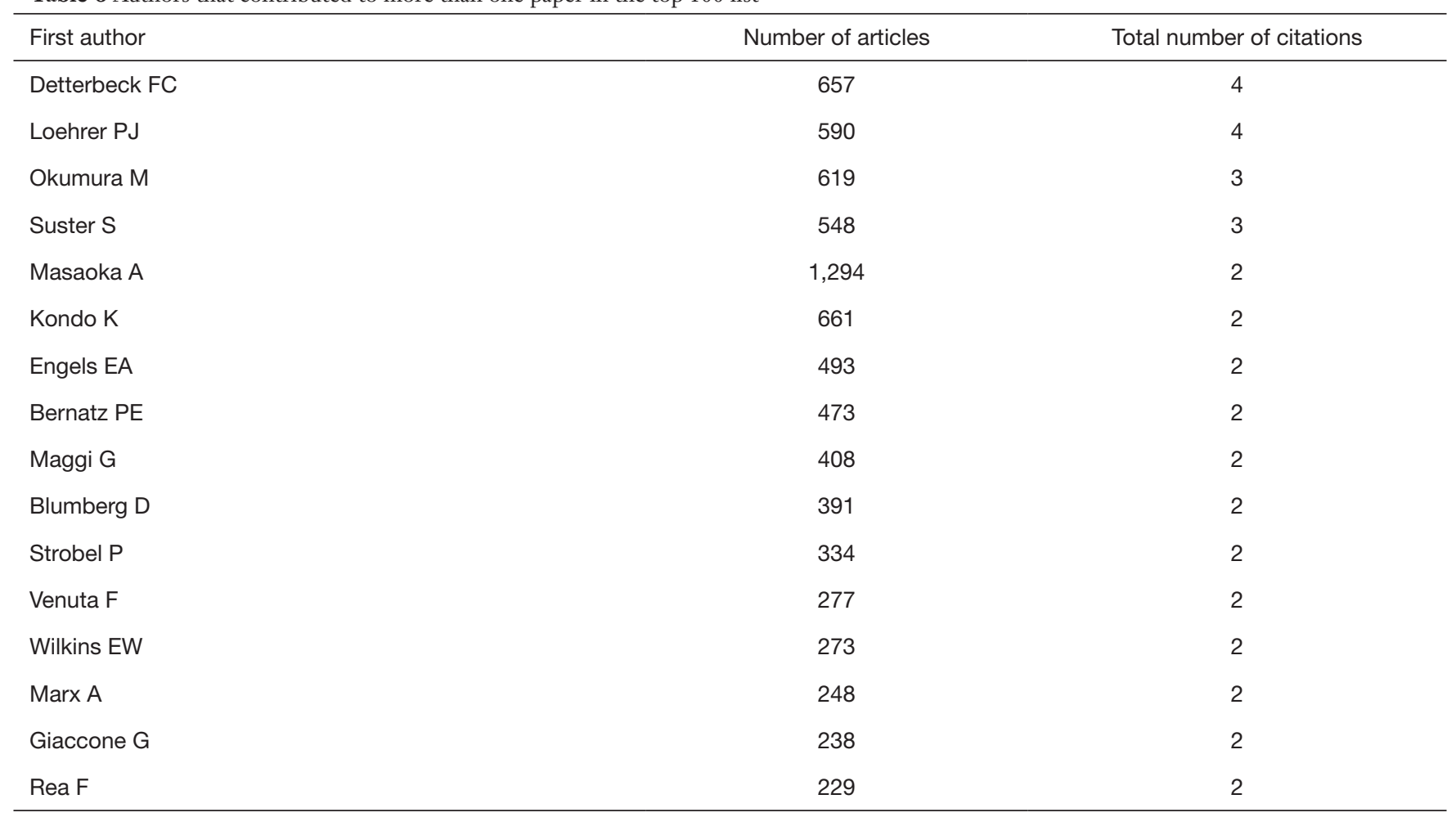

Table 7 Level of evidence of the papers in the top 100 list

\begin{tabular}{lccc}
\hline & Level of evidence & Article type & No. of articles \\
\hline NHMRC & CEBM & Guidelines & 5 \\
II & 1 & RCT & 4 \\
III-2 & 2 & Original prospective & 5 \\
III-3 & 3 & Original retrospective & 7 \\
& 4 & Case report & 8 \\
\hline
\end{tabular}

CEBM, University of Oxford Centre for Evidence-Based Medicine; NHMRC, National Health and Medical Research Council of Australia; $\mathrm{RCT}$, randomized controlled trial.

list (Table 8), with five authors contributing six or more, and one author (Marx) reaching eight.

\section{Discussion}

The higher citation rate of papers published in recent years indicates that these papers will gain more citations in the next few years and thus become more influential. Among the 10 papers with highest citation rate, nine of which were published after 2002 (citation rate: 16.71-30.51).

Among the 10 highest citation rate papers, there are four papers on the staging system of TETs, four papers on large-sample retrospective studies, one guideline, and one review. The most cited paper with the highest citation rate 
Table 8 Authors who contributed four or more papers to the top 100 list

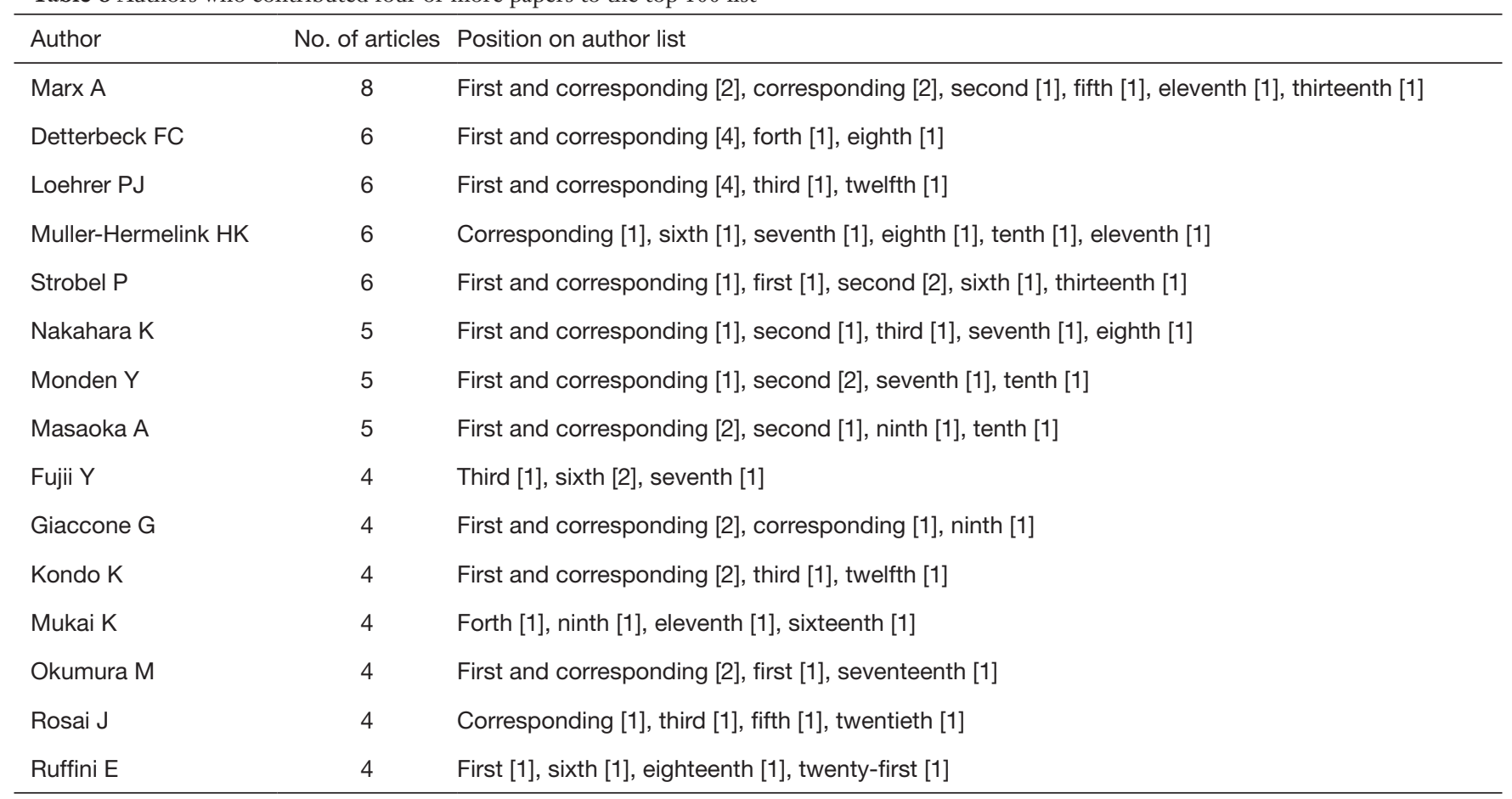

is the "Follow-up study of thymomas with special reference to their clinical stages" written by Masaoka ( $\mathrm{n}=1,190$ citations) from Osaka University, Japan. This paper was the only one to elicit more than 1,000 citations, which proposes the Masaoka staging system widely used in clinical practice. Four of the top 10 citation-rate papers studied the staging system, which was the basis for studying TETs.

The publication of these four papers is as follows: in 1981, Masaoka et al., after analysing 93 patients, proposed a four-stage Masaoka staging system (Follow-up study of thymomas with special reference to their clinical stages, $\mathrm{n}=1,190$ citations, citation rate $=30.51$ ); in 1994, Koga et al . revised the Masaoka staging system after analysing 79 patients, and the revised Masaoka-Koga staging system has since been widely used (A review of 79 thymomas: modification of staging system and reappraisal of conventional division into invasive and noninvasive thymoma, $\mathrm{n}=449$ citations, citation rate $=26.41$ ); however, both the Masaoka staging system and the Masaoka-Koga staging system as revised by Koga incorporate certain vague terminological definitions, leading to possible confusion, therefore, in 2011, the International Thymic Malignancies Interest Group (ITMIG) published clearer definitions and explanations on many details of the Masaoka-Koga staging system (The Masaoka-Koga stage classification for thymic malignancies: clarification and definition of terms, $\mathrm{n}=152$ citations, citation rate $=16.89$ ); in 2014, both ITMIG and the International Association for the Study of Lung Cancer (IASLC) published a new staging system, for the $8^{\text {th }}$ TNM on TETs [The IASLC/ITMIG thymic epithelial tumors staging project: proposal for an evidence-based stage classification system for the forthcoming $\left(8^{\text {th }}\right)$ edition of the TNM classification of malignant tumors, $\mathrm{n}=140$ citations, citation rate $=23.33]$.

Among the 10 highest citation-rate papers, four were large-sample retrospective studies, which were related to the characteristics of TETs. Although TETs are considered as malignant tumours, most of them are inert tumours with good prognosis, making prospective studies more difficult. Therefore, database-based retrospective studies have become the most common way in which to study TETs.

The large proportion of retrospective studies may be related to the better prognosis of TETs. In 2016, Fukui et al. conducted a retrospective analysis on the prognosis of surgical treatment of TETs. The results indicated that the 5- and 10-year survival rates of patients with TETs were $91 \%$ and $81 \%$ (7). In 2017, Tseng et al. conducted a longterm follow-up of 235 patients with TETs. The median follow-up time was 105 [12-198] months, and the OS rate of the patients was $94.4 \%$ (8). These studies have shown that patients with TETs have a good prognosis, and long- 
term prospective clinical trials may consume considerable manpower and financial resources. Therefore, most of the studies related to TETs conducted as retrospective studies.

Most papers were published in the Cancer $(n=19)$, followed by Annals of Thoracic Surgery $(\mathrm{n}=12)$ and Fournal of Thoracic and Cardiovascular Surgery $(\mathrm{n}=11)$. Most papers were published in the cognate area of oncology $(n=43)$, rather than in surgery journals $(n=34)$ and general journals $(\mathrm{n}=10)$. As a result, oncology-related journals had published the most papers related to TETs.

Eleven papers were published relating to pathology. The most cited paper was "Thymoma and other tumors of thymus — an analysis of 107 cases" by Lattes ( $\mathrm{n}=386$ citations) from Columbia University, USA published in 1962, which proposed the histological classification system widely used in the practice of pathology. This traditional histological classification system of thymomas was based on the proportion of non-neoplastic lymphoid cells as compared to neoplastic epithelial cells, which classify thymoma as predominantly lymphoid, predominantly spindle cell, predominantly epithelial, and predominantly rosetteforming.

The second most cited paper with the highest citation rate is "Thymoma and thymic carcinoma" by Marino ( $\mathrm{n}=317$ citations, citation rate $=9.06$ ) from Ospedale San Giacomo, Italy, which proposed a histological classification to classify TETs into medullary, cortical, and mixed tumours, published in 1985. In 1999, Suster presented a proposal for a novel approach to the histologic classification of primary TETs that was based on morphological features of differentiation (Thymoma, atypical thymoma, and thymic carcinoma- a novel conceptual approach to the classification of thymic epithelial neoplasms, $\mathrm{n}=126$ citations, citation rate $=6$ ).

Since 2000, biomarker investigation and immunological findings have been devoted to the progress of assessment of the pathology of TETs. In 2004, Pan found that KIT (CD117), a tyrosine kinase receptor, is involved in the pathogenesis of thymic carcinomas, which express infrequently in thymoma [KIT (CD117) is frequently overexpressed in thymic carcinomas but is absent in thymomas, $\mathrm{n}=133$ citations, citation rate $=8.31]$. In addition, mutations and expressions of EGFR and IGF-1R also appear in thymic tumours (9-13).

The limitations of this study are as follows: (I) most papers always tended to cite papers in more prestigious journals, thus some high-quality papers published in journals with lower impact factors would be ignored; (II) this study only included papers written in English; (III) papers published earlier usually elicited more citations, so we used the citation rate to solve this problem, however, no paper has been included in the past 5 years. The most recently included paper is the 2015 World Health Organization "The 2015 World Health Organization classification of tumors of the thymus continuity and changes" $(\mathrm{n}=141$ citations, citation rate $=28.20)$ published by Marx in 2015 . We can see that only newly published papers with a high citation rate have the chance to be included in the top 100 papers, which is likely to induce historical bias. As a result, new techniques, new ideas, and new directions cannot be captured timeously. We partially corrected this problem by introducing citation rate; (IV) we did not count co-authors other than the first author, which may ignore the contributions of some authors.

\section{Conclusions}

This is the first study of bibliometric analysis as related to TETs, which analysed the year of publication, first author, country of the first author, institution, journals, type of paper, number of citations, and citation rate of 100 most cited papers.

Researchers and clinicians can offer insight into the topic of TETs through this study, which can provide guidance for future TETs research.

\section{Acknowledgments}

Funding: This study was supported by grants from the National Key Research Project of China (Grant No. 2017YFC0113502) and Key Research Project of Sichuan Province (No. 2020YFS0249).

\section{Footnote}

Conflicts of Interest: All authors have completed the ICMJE uniform disclosure form (available at http://dx.doi. org/10.21037/jtd-20-2706). All authors report grants from Ministry of Science and Technology of the People's Republic of China, grants from Sichuan Provincial Department of Science and Technology, during the conduct of the study.

Ethical Statement: The authors are accountable for all aspects of the work in ensuring that questions related to the accuracy or integrity of any part of the work are appropriately investigated and resolved. 
Open Access Statement: This is an Open Access article distributed in accordance with the Creative Commons Attribution-NonCommercial-NoDerivs 4.0 International License (CC BY-NC-ND 4.0), which permits the noncommercial replication and distribution of the article with the strict proviso that no changes or edits are made and the original work is properly cited (including links to both the formal publication through the relevant DOI and the license). See: https://creativecommons.org/licenses/by-nc-nd/4.0/.

\section{References}

1. Engels EA. Epidemiology of thymoma and associated malignancies. J Thorac Oncol 2010;5:S260-5.

2. Venuta F, Anile M, Diso D, et al. Thymoma and thymic carcinoma. Eur J Cardiothorac Surg 2010;37:13-25.

3. Huang J, Detterbeck FC, Wang Z, et al. Standard outcome measures for thymic malignancies. J Thorac Oncol 2010;5:2017-23.

4. Agarwal A, Durairajanayagam D, Tatagari S, et al. Bibliometrics: tracking research impact by selecting the appropriate metrics. Asian J Androl 2016;18:296-309.

5. NHMRC additional levels of evidence and grades for recommendations for developers of guidelines. Canberra: National Health and Medical Research Council, 2009.

6. Group OLoEW. The Oxford 2011 levels of evidence. Available online: https://www.cebm.net/2016/05/ocebmlevels-of-evidence/

Cite this article as: Qiu G, Wang F, Zhang H, Zheng Y, Wang Z, Wang Y. The 100 most cited papers on thymic epithelial tumours: a bibliometric analysis. J Thorac Dis 2020;12(12):7402-7415. doi: 10.21037/jtd-20-2706
7. Fukui T, Fukumoto K, Okasaka T, et al. Prognostic impact of tumour size in completely resected thymic epithelial tumours. Eur J Cardiothorac Surg 2016;50:1068-74.

8. Tseng YC, Tseng YH, Kao HL, et al. Long term oncological outcome of thymoma and thymic carcinoma - an analysis of 235 cases from a single institution. PLoS One 2017;12:e0179527.

9. Aisner SC, Dahlberg S, Hameed MR, et al. Epidermal growth factor receptor, C-kit, and Her2/neu immunostaining in advanced or recurrent thymic epithelial neoplasms staged according to the 2004 World Health Organization in patients treated with octreotide and prednisone: an Eastern Cooperative Oncology Group study. J Thorac Oncol 2010;5:885-92.

10. Girard N, Shen R, Guo T, et al. Comprehensive genomic analysis reveals clinically relevant molecular distinctions between thymic carcinomas and thymomas. Clin Cancer Res 2009;15:6790-9.

11. Girard N, Teruya-Feldstein J, Payabyab EC, et al. Insulinlike growth factor-1 receptor expression in thymic malignancies. J Thorac Oncol 2010;5:1439-46.

12. Suzuki E, Sasaki H, Kawano O, et al. Expression and mutation statuses of epidermal growth factor receptor in thymic epithelial tumors. Jpn J Clin Oncol 2006;36:351-6.

13. Zucali PA, Petrini I, Lorenzi E, et al. Insulin-like growth factor-1 receptor and phosphorylated AKT-serine 473 expression in 132 resected thymomas and thymic carcinomas. Cancer 2010;116:4686-95. 